\section{Nutrient Uptake of Miscanthus in vitro Cultures}

\author{
Szilárd Tóth - Pál Pepó \\ University of Debrecen, Centre of Agricultural Sciences, \\ Faculty of Agricultural Sciences, \\ Department of Genetics and Plant Breeding, Debrecen
}

\section{SUMMARY}

The large biomass production and the low necessary input fertilizer make Miscanthus an interesting, potential non-food crop with broad applications, e.g. for fuel and energy, for thatching, fiber production, for the paper and car industries, as well as for ethanol production.

Axillary buds of Miscanthus x giganteus were placed on a shoot inducing nutrient solution (modified Murashige and Skoog, 1962), basic medium supplemented with $0,3 \mathrm{mg} \mathrm{l}^{-1}$ 6-Benzylaminopurin. After 40 days of culturing, the axillary buds produced three times more shoots than could normally be harvested. The nutrient content ( $N, P, K, C a, M g)$ was measured several times during culturing. The results showed that, after 35 days, nitrogen and phosphate were nearly completely taken up. From that time, shoot growth was not observed.

After shoot propagation, the plants were transfered into a nutrient solution for root formation (modified Murashige and Skoog, 1962), basic medium supplemented with $0,5 \mathrm{mg} \mathrm{l}^{-1}$ Indole3-Butyric acid, and could be potted in soil after about 14 days.

\section{INTRODUCTION}

Miscanthus is a temperate perennial crosspollinating grass used commercially as an ornamental plant. Its large biomass production, and the low input of fertilizer needed make Miscanthus and Arundo donax interesting potential non-food crops with broad applications e.g. for fuel and energy, for thatching, as fiber for the paper and car industries, and for ethanol production (El Bassam, 1996). The species can be vegetatively propagated by rhizome division (Nielsen, 1987) or by in-vitro propagation using axillary shoots (Nielsen et al., 1995).

In species such Miscanthus sinensis and Arundo donax, which are difficult to multiply by seed and reproductive organs, the development of an efficient in-vitro culture system offers methods for propagation with the advantage that a large number of plantlets can be produced at reasonabl, low cost, and can also be useful for breeding purposes.

\section{MATERIALS AND METHODS}

\subsection{Axillary bud culture}

\subsubsection{Shoot induction}

Plant material of 2 different Miscanthus $\mathrm{x}$ giganteus origins were obtained from field plants. The plant material was surface sterilized with $80 \%$ alcohol. Axillary buds were placed on a shoot, inducing nutrient solution. This medium a modified MS basal medium (Murashige and Skoog, 1962) supplemented with $20 \mathrm{~g} \mathrm{l}^{-1}$ sucrose, and $0,3 \mathrm{mg} \mathrm{l}^{-1}$ 6-Benzylaminopurin for the shoot induction. In the nutrient solution, the $\mathrm{pH}$ was adjusted to 5,7 prior to autoclaving. Explants were incubated with a day length of $16 \mathrm{~h}$ at $21{ }^{\circ} \mathrm{C}$ in glass culture dishes. Throughout the whole culture duration $\left(10^{\text {th }}-60^{\text {th }}\right.$ day, every $10^{\text {th }}$ days), the nutrient content of the culture medium $(\mathrm{N}, \mathrm{P}, \mathrm{K}, \mathrm{Ca}, \mathrm{Mg}$ ) of the 2 genotypes was determined by Kjeldahl-method, AAS and photometer.

\subsubsection{Root induction}

After shoot propagation, the plants were transferred into a nutrient solution for root formation. This solution was a modified MS basal medium (Murashige and Skoog, 1962) supplemented with 20 $\mathrm{g} \mathrm{l}^{-1}$ sucrose, and $0,5 \mathrm{mg} \mathrm{l}^{-1}$ Indole-3-Butyric acid for root formation. The $\mathrm{pH}$ value was in the nutrient solution adjusted to 5,7 prior to autoclaving. Shoots were incubated in glass test tubes with a day length of $16 \mathrm{~h}$ at $21^{\circ} \mathrm{C}$.

\section{RESULTS}

After 40 days of culturing, three times more shoots originating from axillary buds were induced.

The results showed that, after 35 days, nitrogen and phosphate in the medium were nearly completely taken up. This means from that time on, no increase of shoot growth will occur. The nitrate content in the nutrient solution decreased steadily up to the $40^{\text {th }}$ day, but stagnated afterwards. This was the same for both genotypes (Figure 1).

\section{Figure 1: Change in nitrate content in the nutrient solution parallel with shoot-growth of two Miscanthus genotypes (G1, G3) during 60 day culturing}

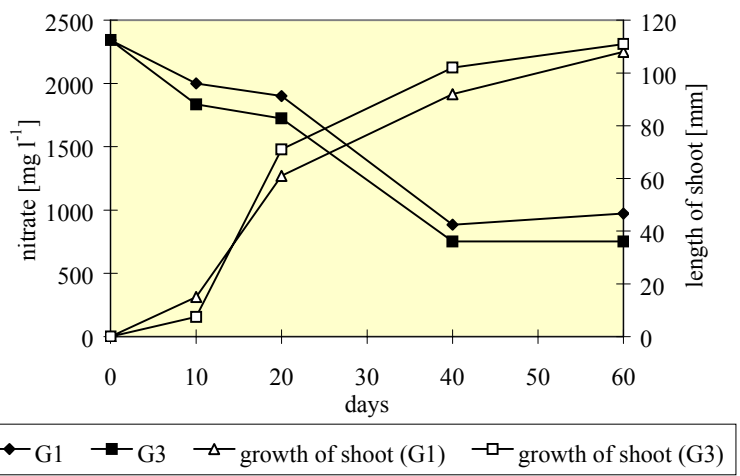


The phosphate content in the medium of both genotypes has already decreased from the beginning of the culture (Figure 2).

In conclusion, phosphate is obviously the limiting element of in-vitro propagation. During the first 20 days, potassium, calcium and magnesium were hardly taken up by the plants. However, after that time, a slow decrease in the uptake of these nutrients could be observed. Up to the $60^{\text {th }}$ day, the plants had enough $\mathrm{K}, \mathrm{Ca}$ and $\mathrm{Mg}$ for their development.

After shoot propagation, they were transfered into a nutrient solution for root formation. After about 14 days, the rooted shoots could be potted in soil.
Figure 2: Change in phosphate content in the nutrient solution in comparison with growth of shoot of two Miscanthus genotypes (G1, G3) during 60 day culturing

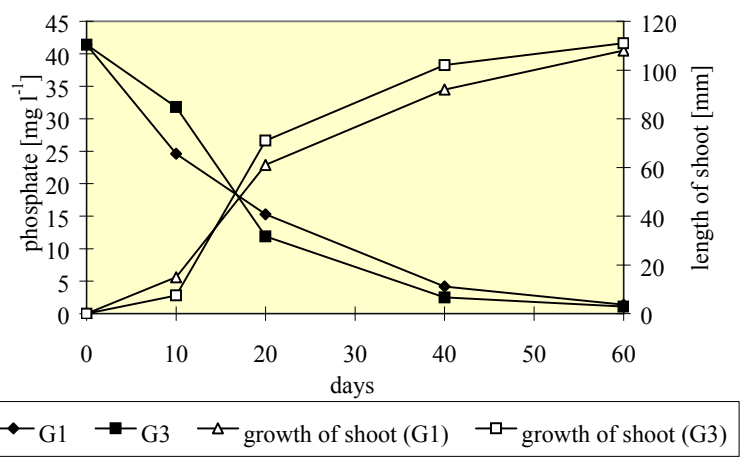

\section{REFERENCES}

Arnoux, M. (1974): Recherchers sur la canne de provence (Arundo donax L.) en vue de sa production et de sa transformation en pate papier. Ann. Amelior. Plantes. Paris, 24. 4. 349-346.

Dalianis, C.-Sooter, C.-Christou, M. (1994): Growth biomass productivity of Arundo donax and Miscanthus sinensis 'giganteus'. 8th E.C. Conference. Abstracts, 191-192.

Dambroth, M. (1989): Industriepflanzenbau ist Rohstoffbasis für die Naturstoffchemie. Agrar-Übersicht Nr. 12. 40 Jahrgang, $65-71$.

Dambroth, M. (1991): Energiepflanzenbau Produktionsalternative oder Stiefkind der Politik? AgrarÜbersicht, 41 Jahrgang. Heft 2, 84-89.

Daniel, G.-Baumann, A. (1991): Pflanzguterzeugung von Miscanthus sinensis L. -Einsatz von in vitro-Techniken-. SuB Heft 3, III-1, III-2

Dehli, A.-Müller, G. (1991): Versuch zum Anbau schnellwachsender Schilfpflanzen im Hinblick auf eine mögliche energetische Verwertung. In: Kuratorium für Technik und Bauwesen in der Landwirtschaft e.V. (KTBL), Darmstadt (Hrsg.), KTBL-Arbeitspapier 158 Miscanthus sinensis, Dokumentation des KTBL-Fachgespräches vom 11./12. September 1990 in Braunschweig, 58-69.

El Bassam, N. (1996): Renewable Energy: Potential energy crops for Europe and the Mediterranean region. Giant reed; Miscanthus (Miscanthus spp.) REU Technical Series 46. Federal Agricultural Research Centre (FAL) Braunschweig, Germany. Food and Agriculture Organisation of The United Nations. Rome, 67-72. 87-94.

Nielsen, J. M.-Brandt, K. (1995): Synergism of thidiazuron and benzyladenine in axillary shoot formation depends on sequence of application in Miscanthus $\mathrm{x}$ ogiformis 'Giganteus'. Plant Cell Tiss. Org. Cult. 41. 165-1707.

Nielsen, P. N. (1987): Vegetativ formering af elefantgraes, Miscanthus sinensis 'Giganteus'. Tidsskr. Planteav 91. 361368 .

Tóth, Sz.-Mix-Wagner, G.-Frahnert, C.-Deuter, M.-El Bassam, N. (1998): In-vitro cultures of different explants of Miscanthus sinensis,Miscanthus x giganteus and Arundo donax genotypes. Biomass for Energy and Industry. $10^{\text {th }}$ European Conference. Würzburg. 1062-1066.

Tóth, Sz.-Mix-Wagner, G.-Frahnert, C.-Deuter, M.-El Bassam, N. (1998): Növény- illetve szaporítóanyag előállítás a különböző Miscanthus genotípusok és az Arundo donax esetében in-vitro kultúrák segítségével. IV. Növénynemesítési Tudományos Napok. Budapest, 130 